\title{
THE ROLE OF CAP RISK MANAGEMENT IN INCOME STABILISATION: EMPIRICAL EVIDENCE OF IST IN SLOVAKIA
}

\author{
Andrea Boháčiková \\ Lecturer at Faculty of Economics and Management, Department of Finance - Nitra, Slovakia \\ andrea.bohacikova@uniag.sk \\ Tatiana Bencová \\ Lecturer at Faculty of Economics and Management, Department of Finance - Nitra, Slovakia \\ tatiana.bencova@uniag.sk
}

\begin{abstract}
In the European Commission (EC) proposals for the Common Agricultural Policy (CAP) post2020 is emphasized the aim to better support the resilience of agricultural systems in the European Union (EU). This resilience is based on the concern that the agricultural sector should be supported in responding to current and future economic, societal, and environmental challenges and risks. Managing risk in farming includes number of activities and strong effort of farms and policy makers. One part of risk management refers to income stabilisation, aimed at decreasing the unstable financial situation and high level of income volatility in European agriculture. In the EU, every year at least 20\% of farmers experience an income loss of more than 30\% compared with their average income in the three previous years. The public instruments to mitigate the income risk of farmers included under the Pillar II (insurance premiums, mutual funds, and the Income stabilisation tool) have been implemented only by very low number of EU countries. In the paper, we analyze the ability to decrease the instability of Slovak farmers with the use of Income stabilisation tool of CAP. The Income stabilisation tool (IST) can be used to indemnify the farmers, who experienced a "severe drop" in income, reflecting the income loss of more than $20 \%$ or $30 \%$ compared to the 3-years average annual income, or the 5-years average annual income, excluding highest and lowest entry (Olympic average). The IST has not been used in the Slovakia, or any other European country operationally so far.
\end{abstract}

Keywords: Income stabilisation tool, Agriculture, Risk management, CAP,

JEL classification: $Q 10, Q 13, Q 14$

\section{INTRODUCTION}

Farmers' income is a key element in EU agricultural policy, aiming at ensuring the welfare for the agricultural producers and the help for farmers facing the risks inherent to their business (Tangermann, 2011). An objective of EU Common Agricultural Policy (Article 39 of the Treaty on the Functioning of the European Union, TFEU), is to increase agricultural productivity, 'thus to ensure a fair standard of living for the agricultural community, in particular by increasing the individual earnings of persons engaged in agriculture' (EC, 2017). Income from farming refers to the sum of revenues the farmer receives from the market, including any form of public support, deducting input costs (EC, 2013). The uncertainties related to farm business (such as extreme weather conditions or market changes) have led, after various policy reforms, to CAP direct payments, supporting farmer income with $72 \%$ of the current EU farm budget (DG Agri, 2018). The other way of supporting farmers and ensure their

http://hdl.handle.net/20.500.12188/15916

http://doi.org/10.47063/EBTSF.2021.0003 
income stability is the use of risk management measures from the Pillar II, especially Income stabilisation tool.

The Income stabilisation tool, defined in the Article 39, Regulation (EU) $n^{\circ} 1305 / 2013$ is a risk management tool for compensating farmers for severe income drop. A severe income drop is defined as a decrease of more than $30 \%$ of the average annual income of the individual farmer in the preceding three-years period, or five-years period excluding the highest and lowest entry (Olympic average). Independent of the source of this income reduction, farmers should receive compensation payments for less than $70 \%$ of the income loss in the year the producer becomes eligible to receive this assistance (EC, 2013; El Benni et al., 2016). Basically, the Income stabilisation tool is a mutual fund that compensates farmers for income losses not production losses. The principal should be that the participating farmers contribute to the mutual fund to establish a financial reserve. Furthermore, the fund obtains the financial support from EU budget. The reserve is used to compensate farmers, who suffer in the next period for income losses, independent of the cause (EU Reg. 8314/2017). The contribution and regulation of IST fund is in competition of individual national agricultural policies. Since January 1st 2018 the IST mechanism has been amended with the Agricultural Omnibus Regulation of European Commission. The threshold rate has been lowered to more than $20 \%$ of average annual income, instead of 30\%. The sector-specific IST, targeting the independent farm sectors, has been added to the toolkit and the calculation of the annual loss of income of the farmer (both general and sector-specific ISTs) based on indexes has been allowed (Meuwissen, 2018; Cordier, 2020). The compensation rate stayed at maximum $70 \%$ of loss. The adjustments have been suggested after unsuccessful implementation of IST in three member states, which had planned to use the tool operationally: Spain, Hungary and Italy. In Italy, there has been problem to monitor the historical income of individual farmers, and the negative attitude to the high level of the threshold rate (Santermo, 2018). In Spain, also the practical measurement of income caused difficulties, as well as the application of IST concerned to specialized dairy producers. In Hungary a great focus has been paid to implement IST, but the lack of guidelines, experience and knowledge caused that it has not been developed so far (Cordier, 2020; Chartier, 2017).

There are also other obstacles and arising questions connected to the implementation of tool. The main criticism states that the risk management tools of EU are more suggestions, rather than effective programs (Vera, 2017; Cordier, 2014). The guideline is hardly insufficient, there is no experience in European or other countries outside with the implementation to national policies, there does not exist public platform to share experiences which could potentially build common benchmarks, and the willingness of farmers to cooperate is often very low. The lack of knowledge about the positive effect of risk management in agriculture leads to disinterest to use the tools and participate. There is a lack of leadership in the farmers' unions, and usually ineffective co-operation between the Ministry of Agriculture and the farmers' unions (Meuwissen et al., 2018). The other problem is the monitoring of historical incomes, as well as the appropriate choice of income variable. There raises also the potential double compensation problem, if farmers use two instruments at once (e.g. insurance premium and IST). Potential threat is the ability of farmers to adjust accounting records in order to obtain IST premium.

Despite of the obstacles in implementation, the scientific research has proved many potential positive effects of the income stabilisation of European farmers. The ex-ante research on the IST focusses on actuarial evaluations of a potential income compensation, governmental costs, impacts on optimal farm programs, and identification of potential beneficiary groups of farms (Mary et al., 2013). In the ex-ante analysis of IST, two basic approaches are employed. The first are the farm level optimization models, which are used to investigate, how the IST affects a specific farm, and how the farmers react to the financial compensation (Turvey, 2012; Mary et al., 2013; Liesivaara et al., 2012). These analyses emphasize the farm-level decision making, 
but are focused on a limited amount of farms. The second are the simulation models, using the bookkeeping data across a large set of farms in years, to investigate income risk of farms and potential indemnification within the IST (Kimura and Anton, 2011; Pigeon et al., 2012). Zgajnar (2017) added the third approach, the regression-based econometric models of data series (Pigeon et al., 2014; El Benni et al., 2016). The main objective of the paper is to evaluate the income instability of Slovak farms in the years $2012-2017$, and the calculate the potential indemnification for Slovak farmers with the use of the Income stabilization tool of CAP. The paper is the further extension of the study Boháčiková et al. (2020).

\section{DATA AND METHODS}

The data used for the analysis consist of the financial statements of individual farms in Slovakia, operating in the period 2009-2017. All information is obtained from the Ministry of Agriculture and Rural Development of Slovak Republic. The final data set is created after outlier removal and consists of 653 farms. Farms are examined according to their legal form and production orientation. The legal forms cooperatives and business companies (Limited liability company and Join-stock company) are taken into account. According to the production orientation, the farms are divided into crop and animal farms. The classification criterion for production orientation is exceeding $50 \%$ share of sales from crop production or animal production to the total sales of own products and services. The structure of data is presented in Table 1.

Table 1. Structure of data

\begin{tabular}{|l|l|c|c|}
\hline & \multicolumn{1}{|c|}{ Category } & Absolute value & \% share \\
\hline Legal form & Cooperative & 336 & $51 \%$ \\
\hline & $\begin{array}{l}\text { Business company } \\
\text { (Ltd. JSC) }\end{array}$ & 317 & $49 \%$ \\
\hline Production orientation & Crop farm & 278 & $43 \%$ \\
\hline & Animal farm & 375 & $57 \%$ \\
\hline Size of land & LPIS more than 500 ha & 121 & $18.5 \%$ \\
\hline & LPIS (500-1000) & 168 & $25.7 \%$ \\
\hline Sum & LPIS more than 1000 ha & 364 & $55.8 \%$ \\
\hline
\end{tabular}

(Source: own processing, LPIS - land parcel identification system)

In order to access the income situation of the farmers, it is necessary to select the appropriate income variable. The European Commission defines the income as the sum of all revenues the farmer receives, including any form of public support, deducting input costs. However, there are several income variables than might be used in the analysis of potential implementation of IST, such as net farm income (El Benni et al., 2016), profit margin (Liesivaara et al., 2012), net value added (Pigeon et al., 2012) and others. In the paper we use the Gross farm income as the income variable to identify the farms that could have received the potential indemnification from CAP, if the Income stabilisation tool had been implemented in Slovakia. Gross farm income refers to the sum of sales from products and services (total output), including sales from crop production, sales from animal production and sales from agroturism, plus the subsidies of non-investment character, deducting the input costs. The input costs are recorded in the account consumption of material, energy and other non-storable supplies and include the costs of fuels, electricity, seeds and seedlings, fertilizers and pesticides, crop protection products, purchased feeds for animals, and total intermediate consumption. The other costs such as wages, rent and interest paid are not taken into account. 


\section{RESULTS AND DISCUSSION}

In order to access the income instability of Slovak farms, and their potential financial compensation of loss, we focused on the income variable - gross farm income (GFI). Firstly, it is necessary to calculate the reference income, as the 3-year average of annual income, and subsequently to quantify the difference between the reference GFI and actual one, in the relevant year (2012-2017). If the difference (loss) exceeded $20 \%$, the farmer could have been indemnified to the maximal level of $70 \%$ compensation of the loss in the certain year. The threshold rate $20 \%$ can be applied for Income stabilization tool since the Agricultural Omnibus from the January 1st 2018, when the amendment of the Regulation (EU) $n^{\circ} 1305 / 201$, Article 36 - 39 has been stated. The initial requirement for income loss was lowered from $30 \%$. In the paper, we take into account both scenarios, and identify farms with more than $20 \%$ loss or $30 \%$ loss. As the reference GFI is recalculated for each individual period, it is possible that the number of identified farms would differ, if the farmers were indemnified in the previous year. In each year, the percentage share of instable farms and the amount of potential indemnification are analyzed. The results are presented in Table 2.

Table 2. The farms eligible for the IST compensation

\begin{tabular}{|c|c|c|c|c|c|c|c|c|c|}
\hline \multirow[t]{2}{*}{ Years } & \multicolumn{2}{|c|}{$\begin{array}{c}\text { Number of } \\
\text { farms with } \\
\text { income loss } \\
\text { exceeding }\end{array}$} & \multicolumn{2}{|c|}{$\begin{array}{c}\text { Share of } \\
\text { farms with } \\
\text { income loss } \\
\text { exceeding }\end{array}$} & \multirow{2}{*}{$\begin{array}{c}\text { Median } \\
(€)\end{array}$} & \multirow{2}{*}{$\begin{array}{c}\text { Max } \\
(€)\end{array}$} & \multirow{2}{*}{$\begin{array}{c}\text { Min } \\
(€)\end{array}$} & \multicolumn{2}{|c|}{$\begin{array}{c}\text { The indemnification in } \\
\text { thous. EUR }\end{array}$} \\
\hline & $\begin{array}{c}20 \% \\
\text { (count) }\end{array}$ & $\begin{array}{c}30 \% \\
\text { (count) }\end{array}$ & $20 \%$ & $30 \%$ & & & & $\begin{array}{c}20 \% \\
\text { threshold } \\
(€)\end{array}$ & $\begin{array}{c}30 \% \\
\text { threshold } \\
(€)\end{array}$ \\
\hline 2012 & 144 & 95 & $22.1 \%$ & $14.5 \%$ & 135933 & 962830 & 10630 & 26195964 & 19653040 \\
\hline 2013 & 112 & 59 & $17.2 \%$ & $9.0 \%$ & 137740 & 736526 & 13765 & 20881238 & 12971121 \\
\hline 2014 & 170 & 100 & $26.0 \%$ & $15.3 \%$ & 157385 & 1576237 & 10538 & 37442077 & 27806668 \\
\hline 2015 & 93 & 50 & $14.2 \%$ & $7.7 \%$ & 151210 & 1730838 & 4087 & 19232809 & 12960661 \\
\hline 2016 & 100 & 52 & $15.3 \%$ & $8.0 \%$ & 157582 & 1578112 & 6047 & 23181934 & 17721007 \\
\hline 2017 & 72 & 49 & $11.0 \%$ & $7.5 \%$ & 152337 & 707448 & 5859 & 14018409 & 11069947 \\
\hline
\end{tabular}

(Source: own processing, adjusted from Boháčiková et al. (2020)

It is not possible to take into account the costs of establishing the Income stabilisation tool fund, as well as the initial contribution of participating farmers. The European Commission allows the Member States to create the own rules in the implementation of the risk management tools to the national policies. In Slovak Republic, the IST has not been implemented so far, therefore the further data and information about the realization of tool in practice are missing. The Income stabilisation tool belongs to the 2014-2020 Common Agricultural Policy and can be applicable since 2014. In the paper, we analyse the longer period, to be able to compare the results and examine the development.

In the year 2012, $22.2 \%$ of farmers reached the level of more than $20 \%$ loss in comparison to the 3-years average annual income, and could have been indemnified with 26.2 mill. EUR in the case of $70 \%$ loss coverage. The number of farms exceeding the $20 \%$ loss level has the declining character during the following years, except for the 2014, when the highest number of farms (170) was identified. The financial compensation from the IST in that year would have reached around 37.5 mill. EUR. The lowest number of farms (11\%), as well as lowest level of indemnification required (11 mill. EUR) was found in 2017. The change of threshold from $30 \%$ to $20 \%$ seems to be step forward in risk management, given the potential ability to support 
more farmers in loss coverage. In the years 2015 and 2016 the changed threshold rate caused almost doubled number of identified farmers.

Figure 1. The farms reaching the loss level for IST indemnification

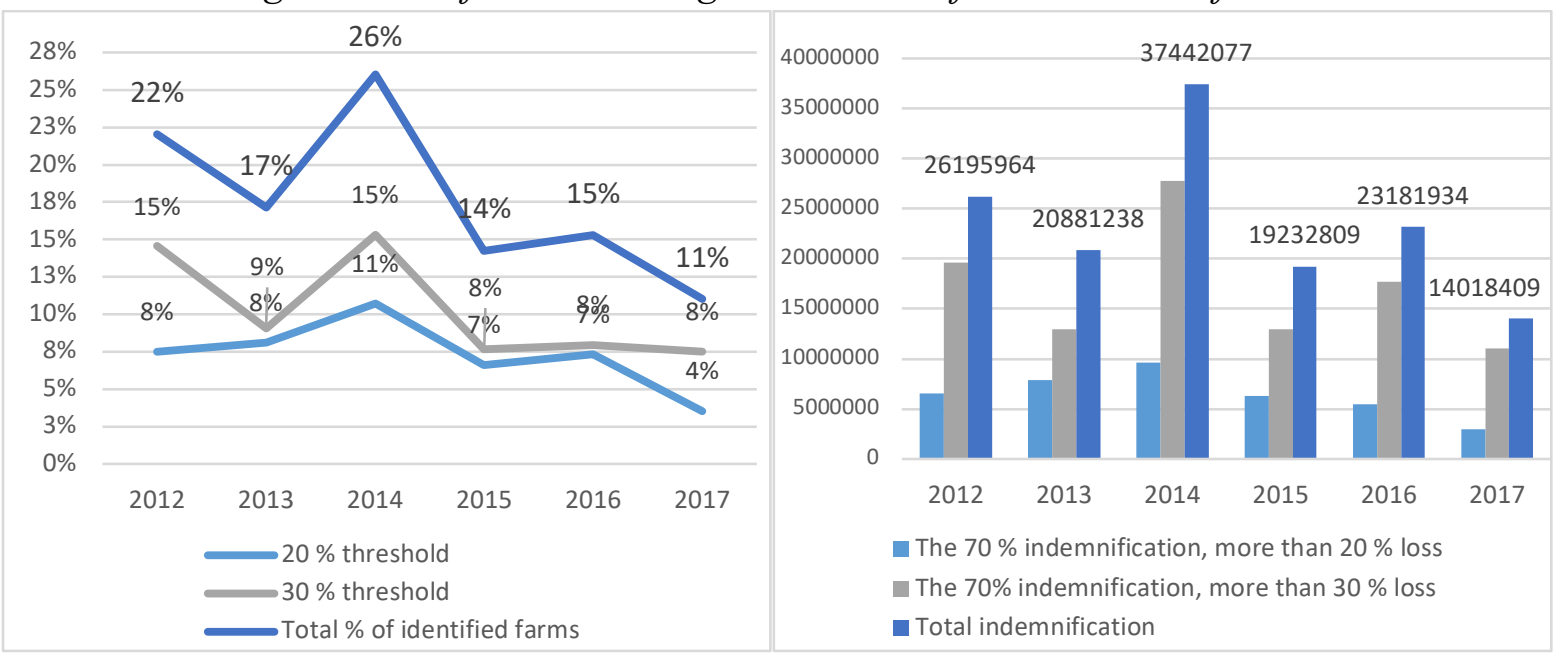

(Source: own processing, adjusted from Boháčiková et al. (2020), value of indemnification expressed in EUR)

Table 3. Differences in legal form and production orientation

\begin{tabular}{|c|c|c|c|c|c|c|c|c|c|}
\hline & All & \multicolumn{4}{|c|}{ Cooperatives } & \multicolumn{4}{|c|}{ Business companies } \\
\hline Year & Count & Count & Share & Total loss & $\begin{array}{c}\text { Potential } \\
\text { indemnification } \\
(€)\end{array}$ & Count & Share & Total loss & $\begin{array}{c}\text { Potential } \\
\text { indemnification } \\
(€)\end{array}$ \\
\hline 2012 & 144 & 66 & $46 \%$ & 18243791 & 12770653 & 78 & $54 \%$ & 19179015 & 13425311 \\
\hline 2013 & 112 & 53 & $47 \%$ & 15086101 & 10560271 & 59 & $53 \%$ & 14744238 & 10320967 \\
\hline 2014 & 170 & 74 & $44 \%$ & 24127706 & 16889394 & 96 & $56 \%$ & 29360976 & 20552683 \\
\hline 2015 & 93 & 40 & $43 \%$ & 10972063 & 7680444 & 53 & $57 \%$ & 16503379 & 11552365 \\
\hline 2016 & 100 & 52 & $52 \%$ & 16970986 & 11879690 & 48 & $48 \%$ & 16146062 & 11302244 \\
\hline \multirow[t]{3}{*}{2017} & 72 & 35 & $49 \%$ & 10003287 & 7002301 & 37 & $51 \%$ & 10023012 & 7016108 \\
\hline & & \multicolumn{4}{|c|}{ Crop farms } & \multicolumn{4}{|c|}{ Animal farms } \\
\hline & & Count & Share & Total loss & $\begin{array}{c}\text { Potential } \\
\text { indemnification } \\
(€)\end{array}$ & Count & Share & Total loss & $\begin{array}{c}\text { Potential } \\
\text { indemnification } \\
(€)\end{array}$ \\
\hline 2012 & 144 & 44 & $31 \%$ & 10571683 & 7400178 & 100 & $69 \%$ & 26851123 & 18795786 \\
\hline 2013 & 112 & 35 & $31 \%$ & 10467477 & 7327234 & 77 & $69 \%$ & 19362862 & 13554004 \\
\hline 2014 & 170 & 82 & $48 \%$ & 28748753 & 20124127 & 88 & $52 \%$ & 24739929 & 17317950 \\
\hline 2015 & 93 & 51 & $55 \%$ & 16550314 & 11585220 & 42 & $45 \%$ & 10925127 & 7647589 \\
\hline 2016 & 100 & 57 & $57 \%$ & 19491070 & 13643749 & 43 & $43 \%$ & 13625978 & 9538185 \\
\hline 2017 & 72 & 35 & $49 \%$ & 11002097 & 7701468 & 37 & $51 \%$ & 9024202 & 6316941 \\
\hline
\end{tabular}

(Source: own processing) 
For the deeper analysis, the farms are divided according to their legal form and production orientation. The table 3 presents the count, \% share of farms experiencing an income loss exceeding $20 \%$, the total loss, and the value of indemnification in the case of $70 \%$ coverage. There is not significant difference in the number of farms with more than $20 \%$ loss of average annual income according to the production orientation. Almost half of the farms are cooperatives and the other one, business companies. Also the level of total loss does not show the comparable differences. It seems, that the character of legal form does not play the role in income situation, as it used to be in Slovakia in previous years.

The comparison of farms, having more than $20 \%$ income loss over the years, and thus the opportunity to gain the financial contribution from IST, according to the production orientation shows, that in 2012 and 2013 almost 70\% of identified farms were the animal farms. During those years the crop agriculture was more profitable and stable, than the animal farmers. The indemnification required to cover the $70 \%$ of loss would have been around 7.5 mill EUR for crop farms, and almost 18.9 mill EUR for animal farms in 2012. In 2013 the percentage share of crop and animal producers remains the same, however the total loss and the compensation differs. Since 2014, after the new CAP programming period, the significant differences between groups have been smoothened. Approximately, half of the identified farms are the crop producers and the second half the animal. It is remarkable, that regardless the number of farms suffering the loss exceeding $20 \%$ (if the majority is crop or animal) the crop farmers experienced higher total loss, and thus would have need higher indemnification in each year since 2014 till 2017.

\section{Figure 2. Income loss and Indemnification based on legal form and production orientation}

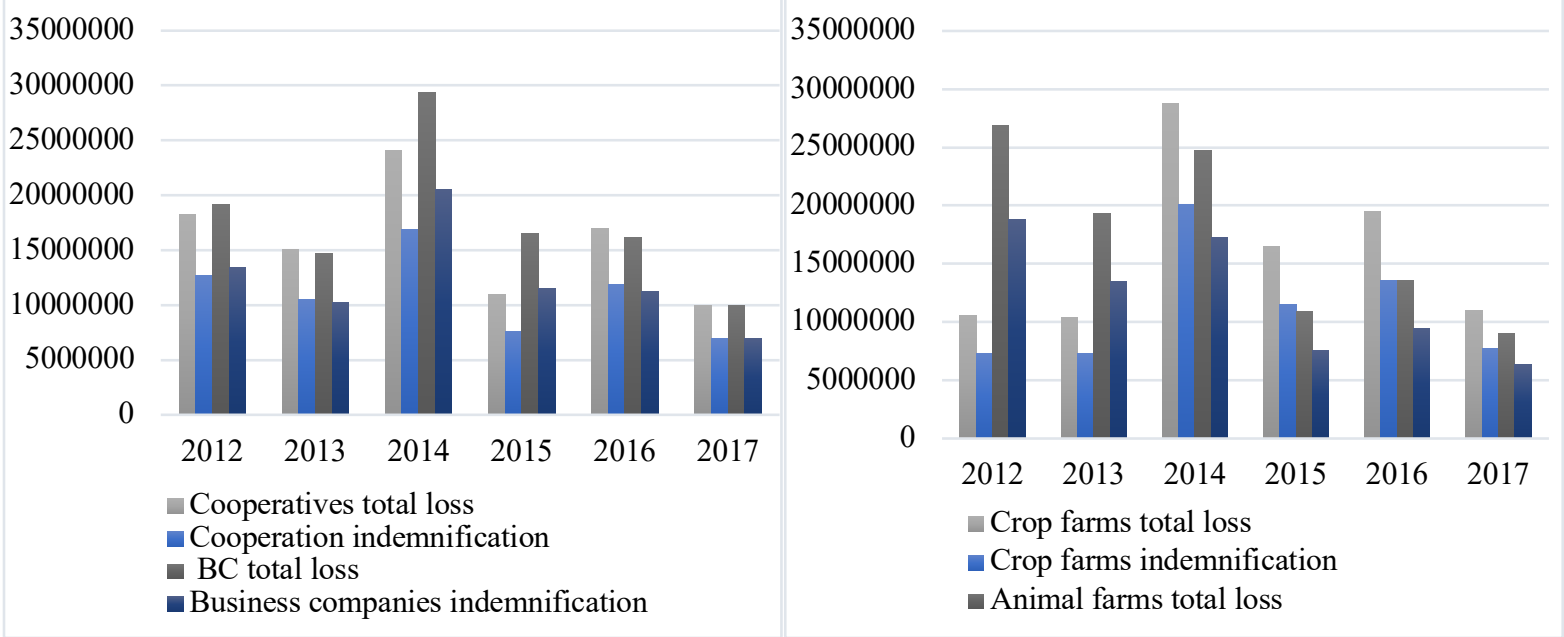

(Source: own processing, value of indemnification expressed in EUR)

The Figure 2. shows the differences in production orientation and legal form of farms experiencing more than $20 \%$ income loss over the period 2012-2017. The lines indicate the $\%$ share of farmers eligible for compensation, and the bars indicate the total loss and the required financial contribution from the Income stabilisation tool fund, if it was implemented in Slovak agriculture. In the year 2017, only 72 farms would have obtained the loss coverage in the total amount of 14 mill. EUR, which is the most positive result from all the selected years. The total loss reached the lowest value, in both crop and animal producers. 


\section{CONCLUSION}

The Income stabilisation tool belongs to one the risk management tools of Common Agricultural Policy, introduced in 2014-2020, aimed at compensating farmers for the negative effects of price volatility and income drops. The tool can be implemented by any EU-Member State to provide up to $70 \%$ compensation of more than $20 \%$ income loss compared to the 3 years average annual income, or 5-years Olympic average. The paper focused on the identification of instable farms in Slovak agriculture, experiencing more than $20 \%$ or more than 30\% loss (previous threshold) during the period 2012-2017. The farms are analysed separately based on the production orientation and legal forms. Both characteristics show only small differences on the in the percentage of eligible farms for compensation. In the paper, we calculated the total loss and the total required indemnification ( $70 \%$ coverage of loss), if the tool had been implemented in Slovakia. The reference income variable, the Gross farm income, has been selected as the most suitable from the point of available data, and EU definition of income from farming.

The CAP allows the Member states to define the own rules for the constitution and management of the IST fund, particularly for the granting of compensation payments to farmers. The countries should firstly prepare administration and monitoring of farms, methodology for arrangement of funds, penalties in case of negligence on the part of the farmer and other steps, that might be costly. None of the EU countries has been using the tools to mitigate the income agricultural risk for now. Even though the millions of EUR could have been refunded to farmers to improve their welfare. The main reason of the unsuccess of the IST are many obstacles and uncertainties in implementation. The guideline is very vague and insufficient, the income definition and income variable choice is confusing, there is an inconsistent accounting system in EU countries, and problem with appropriate monitoring of individual farms. One of the conditions is the creation of IST fun with the active participation and initial contribution of farmers, that may be considered with unwillingness. Moreover, the budgetary needs of the IST can be very volatile and quite demanding. If the scheme is implemented in all Member States, the maximum budget needs for one year are estimated at 22 billion EUR (EC, 2017). To be able to encourage the risk management in Slovak agriculture, it is important to pay attention to the education of farms in this field, dissemination of knowledge about abilities for risk mitigation, support of risk management tools from the government, as well as the focus of scientific research on the potential effects on agriculture business.

\section{Acknowledgement}

This paper is supported by the project VEGA 1/0735/21 Role, financial needs and risks of small farms in Slovakia.

\section{REFERENCES}

Agri, D. G. (2017), "Modernising and simplifying the CAP, Background Document Economic challenges facing EU agriculture", pp. 3-36, Brussel, European Comission, available at: https://ec.europa.eu/info/sites/default/files/food-farming-

fisheries/key policies/documents/env background final en.pdf (accessed 19 May 2021).

Chartier, O., Cronin, E., Jongeneel, M., van Asseldonk, M., Bergevoet, R., Cordier, J., GielenMeuwissen M. and Bocci, M. (2017), "Study on Risk Management in EU Agriculture", DG AGRI, Brussels, European Commission, available at: https://op.europa.eu/en/publicationdetail/-/publication/5a935010-af78-11e8-99ee-01aa75ed71a1 (accessed 19 May 2021).

Boháčiková, A., Bencová, T., Kapustová, Z. and Strápeková, Z. (2020), "The Potential Indemnification of Slovak Farmers with the Income Stabilisation Tool", Visegrad Journal on 
Bioeconomy and Sustainable Development, Vol. 9 No 2, pp. 78-81, doi: 10.2478/vjbsd-20200016.

Cordier, J. (2014), "Comparative analysis of risk management tools supported by the 2014 Farm Bill and the CAP 2014-2020", IP/B/AGRI/IC/2014-044, Strassburg, Parlement Européen. Cordier, J. and Santeramo, F. (2020), "Mutual funds and the Income Stabilisation Tool in the EU: Retrospect and Prospects", EuroChoices, Vol. 19 No. 1, pp. 53-58.

El Benni, N., Finger, R. and Meuwissen, M. P. (2016), "Potential effects of the income stabilisation tool (IST) in Swiss agriculture", European Review of Agricultural Economics, Vol. 43 No. 3, pp. 475-502.

European Commission. (2013), "Regulation (EU) No 1305/2013 of the European Parliament and of the Council of 17 December 2013 on support for rural development by the EAFRD and repealing EC No 1698/2005", OJ L (Official Journal European Union L 347/487), 347, pp. 487-548.

European Commission. (2017), "Summary of main changes introduced to the four basic regulations of the CAP through the Omnibus regulation", available at: https://ec.europa.eu/agriculture/capoverview/summary-changes-omnibus_en.pdf (accessed 19 september 2020).

Kimura, S. and Anton, J. (2011), "Farm income Stabilization and Risk Management: Some Lessons from Agristability Program in Canada", paper presented at the International Congress of the European Association of Agricultural Economists, 30 August-2 September, Zurich, Switzerland.

Liesivaara, P., Myyra, S., and Jaakkola, A. (2012), "Feasibility of the income stabilisation tool in Finland", working paper [no. 706-2016-48385], 123 ${ }^{\text {rd }}$ Seminar, Dublin, Ireland, February $23 \mathrm{rd}-24^{\text {th }}$.

Mary, S., Santini, F. and Boulanger, P. (2013), "An Ex-Ante Assessment of CAP Income Stabilisation Payments using a Farm Household Model", paper presented at the 87th Annual Conference of the Agricultural Economics Society, 8-10 April 2013, University of Warwick, United Kingdom.

Meuwissen, M. P., Assefa T. T. and Van Asseldonk, M. A. (2013), "Supporting insurance in European agriculture: Experience of mutuals in the Netherlands", EuroChoices, Vol. 12 No. 3, pp. 10-16.

Meuwissen, M. P., Van Asseldonk, M. A. and Huirne, R. B. (2008), Income stabilisation in European agriculture: design and economic impact of risk management tools, Wageningen Academic Publishers.

Meuwissen, M.P.M., Mey, Y.d. and Van Asseldonk, M. (2018), "Prospects for agricultural insurance in Europe" Agricultural Finance Review, Vol. 78 No. 2, pp. 174-182.

Pigeon, M., de Frahan, B. H. and Denuit, M. (2014), "Evaluation of the EU proposed farm income stabilisation tool by skew normal linear mixed models", European Actuarial Journal, Vol. 4 No. 2, pp. 383-409.

European Commission. (2013), "Regulation (EU) No 1305/2013 of the European Parliament and of the Council of 17 December 2013 on support for rural development by the European Agricultural Fund for Rural Development (EAFRD) and repealing Council Regulation (EC) No 1698/2005", Brussels.

Santeramo, F.G. (2018), "Imperfect information and participation in insurance markets: evidence from Italy", Agricultural Finance Review, Vol. 78 No. 2, pp. 193-194.

Tangermann, S. (2011), "Risk management in agriculture and the future of the EU's Common Agricultural Policy", ICTSD Programme on Agricultural Trade and Sustainable Development, Issue Paper 34, Geneva.

Turvey, C.G. (2012), "Whole Farm Income Insurance", The Journal of Risk and Insurance, Vol. 79 No. 2, pp. 515-540 
Vera, A. C. and Colmenero, A. G. (2017), "Evaluation of risk management tools for stabilising farm income under CAP 2014-2020", Economía agraria y recursos naturales, Vol. 17 No. 1, pp. 3-23. 